original sial crust has been buried beneath at least 7 and probably 10 or more kilometres of basalt that it has become mobile and has migrated outward from the place of deepest burial so that the sialsima junction approaches parallelism with the geoid. Such migration of sial to the west (as shown in Text-fig. 3) may form part, but not the whole, of the support for the dome from which the high coastal mountains are formed. In the same way migration of sial from under the Denmark Strait to the east may have provided the sial support for Iceland which Hawkes and his co-workers have postulated. ${ }^{1}$ The removal of some of the sial layer beneath the Denmark Strait would allow the surface of the basalts to sink below sea level. The strait is for the most part quite shallow, but there is evidence that recent deposition of sediments is the cause. If a process of this sort; actually occurs it is capable of extending the ocean basins, and indeed may have been, in very early times, a factor in their formation.

\title{
CORRESPONDENCE.
}

\author{
CAIRNSMORE OF FLEET GRANITE.
}

SIR,-There is an unfortunate error in our paper on the Cairnsmore of Fleet granite published in the Geological Magazine for July, 1937. On page 296 the position of the monchiquite dyke [74] is wrongly given. It occurs in the Little Water of Fleet intrusive in the granite about 40 to 50 yards from the margin of that rock. As this rock is an exceptional one, it is desirable to make this correction.

C. I. Gardinkr.

S. H. REYNOLDS.

The University, Bristol.

\section{A PLEISTOCENE STRAND LINE IN THE VALE OF YORK.}

Sir,-Mr. Sidney Melmore, writing to the Geological Magazine for October, 1937, quotes part of a paragraph of mine (Proc. Yorks. Geol. Soc., xxiii, 1936, 115) which leads him to infer " the spectacle of a river terrace some $\mathbf{4 0}$ feet below its presumed base level". Had he considered the rest of the paragraph he might have avoided

1 Cargill, H. K., Hawkes, L., and Ledeboer, J. A., "The Major Intrusions of South Eastern Iceland," Quart. Journ. Geol. Soc., lxxxiv, 1928, 534. 
this misunderstanding. Mr. Melmore appears to be confusing the base level of "erosion" which was at that time controlled by the 100 Foot Submergence and the base, or lowest possible level of "deposition" which was determined by the depth of the river valley already in existence. "Certain patches of sand-which appear to be of Higher Terrace age " do indeed lie below the 100 Foot Strand Line at Ferrybridge; they were deposited under water in the submerged area which extended several miles farther upstream.

Mr. Melmore dismisses my correlation of Airedale terraces as ambiguous and likely to lead to serious confusion. His simple alternative is to ignore the existence of a Lower Terrace and, apparently, to include the Higher Terrace in a group of " 20 Foot terraces" of late Hessle age, presumably common to other dales, which must "fan out into the sands and silts which fill the Vale of York up to about 50 feet O.D." Firstly, a reference to the Ordnance Survey maps will show that there are no such 50 foot deposits in the Vale of York contiguous to lower Airedale. Secondly, if the Higher Terrace is of "late Hessle age", what is the age of the later Lower Terrace, which, far from being absent, is a bulky fluvio-glacial deposit contemporary with the last Dales glaciation? Thirdly, where does the Leeds Hippopotamus fit into this scheme? I have referred to Mr. Melmore's book, p. 88, and do, of course, give him credit for the conclusion that this animal lived in interglacial times. But why does he correlate it with the Woodlesford deposits, which are in the Higher Terrace (" 20 Foot Terrace" of Mr. Melmore), and therefore, on his showing, late Hessle?

May I deprecate the use of such meaningless terms as " 10 Foot Terrace" and "20 Foot Terrace"?

YoRK.

WILFRID EDWARDS.

6th December, 1937.

\section{REPORTS AND PROCEEDINGS.}

\section{Mineralogidal Soctety}

4th November, 1937.

(1) "Scawtite pseudomorphs after spurrite at Scawt Hill, Co. Antrim." By Professor C. E. Tilley.

(2) "The occurrence of acmite in the riebeckite-microgranite of Mynydd Mawr, Caernarvonshire." By Dr. S. R. Nockolds.

The previously unidentified mineral, occurring as colourless or pale yellow acicular crystals, in the riebeckite-microgranite of Mynydd Mawr, is now shown to be acmite. As it is quite plentiful in the thin sections, examined it is suggested that riebeckite-acmite-microgranite would be a more correct term for the rock. 